\title{
Prosecutors in multi-level governance structures - introduction
}

\author{
Marianne L. Wade \\ Published online: 10 January 2013 \\ (C) The Author(s) 2013. This article is published with open access at Springerlink.com
}

In dealing with issues of government today, the concept of multi-level governance is an important one. Perhaps not surprisingly in our societies "governed through crime," criminal justice is one of the mechanisms also being drawn into such complex structures of government.

The crime of terrorism most notably sparked a revolution with the notorious resolution 1373 which saw the Security Council acting as a criminal law legislator and the creator of punitive sanctions (the so-called smart-sanctions). This most extreme example perhaps drew our attention to what holds true in other contexts. The UN but especially the European Union provide examples of entities created by the sovereign will of their constituent states now taking on a governance role of their own, also at the core of sovereignty as traditionally understood: in the criminal justice realm.

For those who have identified the prosecutor as a king-pin of national criminal justice systems (see e.g. [7]), this raises the desire to see what these often underestimated (at least in European literature) actors are making of such new settings. Concerns raised about the social effect of these quasi-judicial workers of the executive as they struggle to balance competing interests in their national arenas [6] clearly take on different significance, in theory alone, as they move onto "higher" stages.

Reality sees the theorists right very fast. Just as the extent of discretion exercised by prosecutors in national systems leads to a need for priority setting and controversy, ${ }^{1}$ decisions to be made about prosecutorial policy in international criminal tribunals is cause for the weighing of tortuous choices. In that setting prosecutors seek guidance how to exercise their discretion when their choice of defendants determines "which mass murderer is brought to justice." Clearly the way in which prosecutorial discretion is used can constitute a key factor in shaping policy.

\footnotetext{
${ }^{1}$ Because prosecutorial decisions not to prosecute are associated with mechanisms to spend the state interest in prosecution (see e.g. [6;p. 22]). These most frequently take the form of fines which are imposed without a formal finding of guilt being made. Although these do not result in a criminal record for the offender, within the Schengen area (currently 33 European states) they do preclude prosecution by another state for the same act. Thus countries which have decided against introducing such mechanisms viewing them as objectionable on principle, will nevertheless be bound by the decision of a prosecutor in another state which allows such solutions [5].

${ }^{2}$ As expressed by an ICTY prosecutor (email on file with the author). On these issues see [1; p. 79 et seq.].

M. L. Wade $(\triangle)$

School of Law, University of Birmingham, Birmingham, UK

e-mail: m.l.wade@bham.ac.uk
} 
Traditionally in continental European settings, prosecutors have been regarded as figures of either the executive or the judicial branch (on this status in EU member states see $[9,10])$. On the one hand they may be regarded as members of a relatively autonomous part of the executive tasked with ensuring justice is enforced on the ground, also in line with any policy the government develops. Other countries, like France, locate them constitutionally as part of the judiciary but place them in hierarchical structures which are accountable to the justice minister. The German stance that they are "judicial members of the executive" sums up the dichotomous nature of the position in which prosecutors are often to be found. ${ }^{3}$

Multi-level governance structures are often identified as populated by bureaucrats, significantly removed from day to day politics and normal structures of accountability, although they exercise powers of government. What then is one to make of prosecutors figures usually working in tension between two arms of state power - within such contexts? This special issue cannot attempt to explore the multitude of issues surrounding the fascinating topic of multi-level governance constellations but it aims to look at this figure within them.

Be prosecutors executive or judicial characters, any position afforded to them in multi-level governance structures; associated above all with informality and a breakdown of structures clearly separating powers, immediately raises important questions. What is a prosecutor within such contexts; what function are they to have and who controls them when they operate in such roles at a governance level devoid of a clearly accountable executive or indeed a judiciary embedded in constitutional structures?

In fact, when one begins to consider such issues one becomes aware that these issues are not entirely new. There are older models of prosecutors in multi-level systems namely within federations; thus far they have perhaps simply not been thought of in this way. The reason for this may be that ultimately all governance structures within them are also unified under a Constitution and at some level serve the same sovereign within one nation state. Tensions are possibly not as obviously evident as they become in internationally constituted structures. Nevertheless it was considered for the purposes of this special issue, that potential lessons may be learned from such structures and how prosecutors operate within them.

For this reason, Boyne provides an account of a well-established system: the German one. There prosecutors are bound by the principle of mandatory prosecution and enforce a Federal code of criminal law according to the procedures of a Federal code of criminal procedure but they do so as state servants of the Länder (the 16 constituent states of the Federal Republic of Germany) structured accordingly in smaller units. Theoretically their work is marked by uniformity but its results are long established as differing significantly. ${ }^{4}$

In an article which presents-results from her inter-view based study, Boyne discovers:

"At each truth finding stage, from the initial investigation of a reported crime to a case's final adjudication, unique combinations of political and cultural factors shape the system's outcomes. In some cases, variations in local legal practice

\footnotetext{
${ }^{3}$ For a definition [8; p. 469].

${ }^{4}$ Thus prosecutors have been found to enforce significantly different reactions to crimes in the northernmost state of Schleswig-Holstein than is the case in Bavaria [2; p. 130].
} 
reflect different customary attitudes towards crime embedded in the traditions of local communities. The confluence of incentives and leadership practices specific to particular organizational entities also shapes the implementation of the law"

Thus in Germany, which one might anticipate to be a fairly homogenous cultural setting:

"To the extent that prosecutors' attitudes towards crime and punishment mirror the attitudes of the local cultures in which they are embedded, differences in attitudinal preferences may prompt rgional differences in how justice is administered throughout Germany"

Consequently Boyne presents food for thought for anyone attempting to create a larger space of legal unification or to ensure the even application of law across and through a diversity of structures. This will, of course be the case when prosecutors are asked to work in multi-level governance structures. She demonstrates all too clearly the tension between the aim of unity or unification and the reality of local justice; the importance of the who and where of criminal justice practice is highlighted as potentially more important than the what of the law. As Boyne asserts:

"The administration of justice in Germany today is filtered through organizational and social lenses that shape how the law is interpreted and applied. The interaction of factors such as incentives, political influence, office structure, and local norms affects the choices that prosecutors make during the investigation and adjudication phases of the criminal justice process. The existence of this variance in practice poses a challenge to the system's underlying values. Although the drafters of the German Code of Criminal Procedure sought to eliminate prosecutorial discretion, the existence of variance demonstrates that discretion exists."

Boyne's findings are, however, not an illustration of futility for those aspiring to ensure law can be applied across diverse structures. Thus she points out:

“in Germany as a whole, the country's civil law tradition and system of basic rights helps to inform the national legal culture. At the Land level, ministerial level instructions and the cultural norms of the Land itself help to structure decision-making. At the regional level, which is drawn by the sphere of authority of each General Public Prosecutor's Office, regional decisionmaking guidelines and decision-making norms establish regional understandings of decision-making parameters. These norms are transmitted to local offices through formal case review processes ... At the level of local prosecutor's offices, the shared oral histories of decision-making norms transmitted from prosecutor to prosecutor, guide routine decision-making. In short, to understand how justice is delivered on the local level, we must understand the local context that frames decisions about proof, facts, guilt, and innocence."

This article thus provides insight into the many layers beyond the law which any attempt at legal unification or to ensure an even application of the law should 
consider. As the evolution of the common law demonstrated: travelling judges were just as important as the doctrine of precedent in ensuring unity. Thus, as Boyne states:

"If policy-makers intend to reinforce the normative foundations of the German criminal justice system, the starting point for initiating change lies in understanding the organizations factors that affect how the law is interpreted and implemented. The decision-making boundaries set by the law serve as the mere starting point for defining the face of justice, to change how prosecutors deliver justice, legislators and civil servants must find ways to put their hands on the organizational controls."

The lessons for those passing discretion in applying the law to prosecutors in multi-level governance settings (and it is almost unimaginable to have prosecutors operating without discretion as Boyne also demonstrates within the German system) is that their training, legal education and understanding will be key if any kind of unity is to be expected.

This point could not be illustrated more clearly than it is in the context explored by Ambos and Stegemiller. Although a very different setting, the Office of the Prosecutor (OTP) of the International Criminal Court (ICC) provides a fascinating look at prosecutors in action in a multi-level system. Given that the ICC stands at the centre of a web which should ensure an end to impunity for international crimes, this policy requires co-ordination and coherence with that of the prosecution services of 121 signatory states who via their own prosecutions (including those invoking universal jurisdiction) should leave the ICC to tackle only the most serious cases or those in which the relevant jurisdictions are unwilling or unable to prosecute (article 17 of the Rome Statute).

The ICC might not be the first institution to spring to mind when discussing multi-level governance though this association will become apparent if one regards the ICC as a legal institution created by bundled executive will to ensure the greatest criminal offences perpetrated against mankind do not go unpunished. Given this governmental aim, prosecutors enforcing that will at ICC level; part of whose job is to decide whether to bring a case at the international court or to work towards delegation to a national level can clearly be seen as working within a multi-level governance structure.

Ambos and Stegemiller critically analyse the ability of the policy documents released to date to guide prosecutors in their choices to aid prosecutors in completing this mandate. They explain:

"The ICC can, in turn, theoretically act on a universal scale. For these reasons, more difficult choices have to be made and selectivity plays an important role. The function of the court, and its legitimacy, stand and fall with such decisions."

In other words, how prosecutors exercise their discretion in this context, and the knock-on effect this has further down the criminal justice chain they serve, is decisive to the entirety of the justice effect served in this context. There can be no clearer illustration of the role played by prosecutorial decisions taken in multi-level governance contexts such as these. All relevant executive power is vested at this level and so prosecutors effectively become the deciding instance of international criminal justice. They are the factual policy-maker at this level deciding who is investigated and charged; who can, in fact, become subject to international criminal law at all. 
For this reason

"given the existing capacity constraints and the goals of the Court to prosecute the "most serious crimes" of the "most responsible.",

The OTP decided to issue policy documents to guide prosecutorial decisionmaking. As Ambos and Stegemiller critically remark, however, a decision was made not.

"to have one main document with the overall general or specific goals of a prosecution strategy" which "indicates the general direction for the Office and this not only for the interested public but also for the personnel working in the Office."

Ambos and Stegemiller therefore lament a missed opportunity to provide for transparency and accountability whilst at the same time contributing to an internal culture in Boyne's sense. They explain:

"The Office has chosen to focus on the most serious crimes and on "those bearing the greatest responsibility". While the latter terminology allows for certain flexibility, the ICC Prosecutor mainly selects the persons from the top of the (state) hierarchy for his cases. Others are left to national criminal justice systems, encouraging territorial and third states to take measures against those offenders and to close the impunity gap."

Ambos and Stegemiller highlight the multi-level nature of the OTP's tasks and the impossibility of satisfactory prosecutorial performance in this context if their work is not recognised as part of such a multi-level system. Thus:

"It is clearly impossible for the ICC to prosecute all potential perpetrators of international core crimes. The ensuing impunity gap can only be closed by prosecutions on the national level. Thus, the success of the OTP's approach, with a view to the fight against impunity, depends on the strength of national systems and their integration into the international criminal justice system as a whole. On a different note, one must not confuse the OTP' policy choice to limit prosecutions to certain high caliber cases with the admissibility threshold as a legal barrier to bring certain cases. If the Prosecutor feels the need to take a broader approach, his policy may be adjusted accordingly, albeit always bearing in mind the need of coherence."

Herein lies a danger of such systems: prosecutors are kingpins and their decisions subject to misinterpretation. It is essential that adequate communication take place or the multi-level function is lost and the ICC can only serve to highlight the fundamental problem:

"The question of whom to prosecute is one that concerns international crimes equally because the number of potential perpetrators is so large that is practically impossible to put everyone on trial." 
This, Ambos and Stegemiller explain:

"In practical terms, positive complementarity means that the Prosecutor will encourage proceedings at the national level rather than taking over a case himself. In other words, even if a case is admissible in terms of the complementarity test, i.e., the respective State is, in principle, either unwilling or unable to investigate and prosecute it ... the Prosecutor might encourage this State to take own action with the assistance of the OTP, without being directly involved in capacity building"

In this way, prosecutors' status as policy-maker and driver becomes evident. Multilevel governance systems are described as networks and often criticised for the lack of accountability which surrounds governance action within them. This article highlights another aspect. Arguably the OTP will be held to account by the Court, the United Nations, and the general public but this demonstrates prosecutors having to exercise very unusual roles for which they are not normally equipped: motivator, driver and indeed politician. Ambos and Stegemiller therefore emphasise the danger associated with such actors performing a role for which they are not prepared.

"However, the problem is that the ICC has not yet determined a firm strategy with respect to parallel proceedings at the national level and that the OTP's prosecutorial practice has been inconsistent ... While in some cases the Prosecutor gave priority to facilitating domestic proceedings (e.g. Colombia;...), regarding Libya it is apparently expected that it actively challenges admissibility. This makes plain that considerable uncertainties exist with regard to the determination of domestic investigations and prosecution strategies in line with the existing admissibility test"

Prosecutors are demonstrated to be stretched by the formulation of their own vital policy and yet are placed in a position in which they need to actively govern others in order to ensure the task entrusted to them is truly done. Prosecutors genuinely then become the master of puppets but in the absence of being handed any strings. The issues associated with accountability of these prosecutors, of course, only grow larger should they manage to exercise such influences.

"In any case, given the high caseload of the ICC, there is no alternative but to promote the exercise of domestic jurisdiction by way of positive complementarity. If the territorial State is not able or willing the ICC may also cooperate with third States."

Prosecutors in this context therefore act as coordinators of a potentially worldwide effort to bring perpetrators to justice. As the authors go on to explain:

"The Prosecutor cannot leave the ambiguous matter of alternative mechanisms entirely to States, but is supposed to monitor any crimes that are not investigated and prosecuted as far as these are related to the concrete situation or cases under investigation ... It is therefore an important task to develop coherent guidelines that specify the requirements for genuine investigations/prosecutions in territorial States." 
We therefore clearly see prosecutors working way beyond their usual remit as Ambos and Stegemiller argue:

"Despite the fact that each case varies and thus a case-specific approach is required, it is feasible and essential for the future work of the ICC to provide guidance on transitional justice mechanisms. From our point of view, the principle of complementarity even obliges the Prosecutor to recommend a proper framework which then may be accepted or corrected by the ICC Judges in a concrete proceeding."

We thus see clearly that prosecutors but even the Court also are required to function as international governance instances advising, guiding, correcting and, logically, reacting. The remit of OTP action, is, however, not at an end even with international governance of criminal justice activity. In a step in line with the parameters of court work (as outlined in particular by articles 53 and 54 of the Rome Statute), prosecutors must also address victims as "Clearly such efforts to address victims and to include them in dialogue would be entirely undermined by a selection strategy which is felt to ignore them." Furthermore "The last principle mentioned by the OTP is to maximize the impact of activities of the Office."

Prosecutors are thus tasked with a large variety of responsibilities here recognised as well beyond their criminal justice remit. They do, however, also have wide-ranging duties in this regard such as ensuring the details of parallel investigations are defined. They are thus also criminal justice actors with the broadest possible remit; investigators also ensuring investigations are run correctly and in consideration of a range of interested parties, responsible for charging, prosecution decisions and trial. Their selection will thus centrally influence the further development and implementation of international criminal law. Ambos and Stegemiller therefore remind us to beware that the core exercise of discretion must be well done because:

"Only if prosecutorial selection is based on well-defined criteria, the Prosecutor's decisions will find support and gain legitimacy" and

"The impunity gap may only be closed or at least diminished through a comprehensive, well coordinated strategy. In any event, questions of prosecutorial discretion with regard to case selection and potential constraints remain the most significant issues in the near future of international criminal justice"

In other words, prosecutors and their decisions are at the heart of making criminal justice work within the international system as it now stands. Above all:

"the ICC Statute does not provide for unlimited, free-standing discretion. The carefully drafted provision, dealing with selection choices, is article 53 ICC Statute. The Prosecutor must therefore adhere to the criteria of this provision, in other words, issues of (discretionary) "gravity" and "those bearing the greatest responsibility" are a matter of article 53 (1) (c) and (2) (c) ICC Statute."

The authors highlight that it is in fact others who should shoulder the responsibility of governance issues so that the OTP can concentrate on its core tasks. Thus they insist: 
"In our view, the Assembly of State Parties and the more powerful ICC Member States must take their responsibility more seriously and assist post-conflict States in their development of criminal justice capacity."

The essence of international criminal law in a multi-level system is that:

"The international criminal justice system operates on three levels in the fight against impunity of international crimes: (i) the level of the territorial States exercising its territorial jurisdiction, (ii) the level of the ICC exercising supranational jurisdiction, and (iii) the level of third States exercising extra-territorial jurisdiction, normally pursuant to the principle of universal jurisdiction. Only a mutual burden sharing between these three levels may efficiently contribute to the closing of the existing impunity gaps. This clearly requires efforts well beyond the capacities of any prosecutor."

A far more obvious candidate for inclusion in any volume concerned with multi-level governance is the European Union (EU - see e.g. Denhousse (2008) [4; p. 7]). Often associated with bureaucracy and criticised for its opaque nature of government, the EU stands before a renewed discussion of a European Public Prosecutor (EPP). EU criminal justice-related agencies have been described as to "intergovernmental legal personality combined with some supranational aspects... already [featuring]... some 'disconnection' from the Member States, since... Eurojust enjoys autonomy from them [in some areas].” [3; p. 142]. This description was written before relatively recent reforms placing Europol and Eurojust on supranational legal bases meaning that this distance from the member states and the level of supra-nationalisation has only increased.

Wade explores the potential for a European public prosecutor as the EU stands poised to consolidate and determine its criminal justice role post the Lisbon-Treaty. Until now both the Commission's anti-fraud office, OLAF and the competition authority have negotiated (non-criminal) investigations in multi-level settings [11; p. 184] so certain structures are already in place. Such proceedings naturally take on a different quality if carried out by a truly supra-national criminal justice agency. For this very reason the member states have traditionally opposed agencies at the EU level becoming endowed with criminal powers to protect the financial interests of the EU as well as its competition laws although such measures can well be regarded as punitive in nature. For this reason the EU to date features bodies such as Europol and Eurojust who provide support to the member states' criminal justice systems from the supra-national level but are described as having no operational powers themselves. The consistently inadequate protection of the financial interests of the EU vociferously proclaimed by the European Commission for at least the last 15 years, however, now see this body set to call for a European public prosecutor to "investigate, prosecute and bring to justice" (article 86 Treaty of the Functioning of the European Union) such cases.

Wade explores this possibilty opened by the Lisbon Treaty. Drawing upon her empirical study, she argues the EU as having a specific relationship to certain types of crimes stating:

"the EU - as a supra-national instance - has interests beyond the collective concerns of the member states. In relation to crimes against its budget, the EU's interests may, in some cases, even be contrary to those of member states. In 
relation to cross-border crime, the EU has sought to make provision for comprehensive investigation and prosecution of these, often significantly boosting the reach of member state action to ensure a different quality of investigation and prosecution. The legitimacy of EU action in such contexts ... is lent particularly by the specific nature of the EU. As a supra-national governance level providing for the free movement of goods, persons, products and capital, it plausibly facilitates crime of different sorts"

The EU is thus identified as a governance level with a potential role relating to crimes beyond those currently focused upon. Discussion of prosecutors within this multi-level setting is thus broader than the current political discussion featuring more comprehensive potential roles for prosecutors. This contribution highlights how such roles might be defined. Wade outlines deficits in current investigations and prosecutions into European cases. These are identified with the help of practitioner interviews and in particular highlight the lacking recognition of cases as European (as opposed to only contained within one member state), the limiting of investigations and prosecutions to matters of interest to the national jurisdiction handling a case, as well as prosecutors' dissatisfaction with their inability to actively pursue leads across borders in financial interest cases.

As Wade argues: "The very idea of creating an EPPO must centrally aim to ensure the internal borders of the EU pose no impediment to prosecuting crime, provide for a full investigation leading to a comprehensive prosecution and then a sentence reflective of the criminal activity involved in its entirety."

However, the controversy of placing prosecutors at this supra-national level within a governance context which is much criticised as it stands, bears specific dangers. Unlike in relation to the ICC, there has, as yet been no clear declaration of political will for any kind of criminal justice governance at this level. Quite the opposite is true. Wade describes her study results as also potentially supporting arguments objecting to such development.

"One might conclude ... that further institutional development at this point would be premature because until the mechanisms in place are being used properly, one cannot truly determine the necessity of any further reform. ... If practitioners report that there is significant room for improvement in the current system, any inadequacies identified can be argued to indicate a need for training and information but not institutional reform."

Thus Wade points out:

"Whilst the EuroNEEDS study clearly points to issues which might be resolved by a European public prosecutor and indeed demonstrates a very significant level of support for such an institution amongst the professionals currently tasked with the kind of work, the opposition it demonstrates cannot be ignored. Even if the political case for a European public prosecutor is made and it is structured suitably ... [a European public prosecutor] cannot work in isolation."

We thus see echoes of the situation Ambos and Stegemiller identified prosecutors as facing within the international criminal law context; as practitioners tasked with central responsibilities but also necessarily in communication and coordinating closely with prosecutors working at the national level. The levels of resistance to a 
European public prosecutor found amongst these nationally based practitioners despite their simultaneous acknowledgement of considerable problems in handling European cases cannot but counsel to particular caution. The EU may provide a singular example of multi-level governance associated with supra-national integration, that does not, however, necessarily forecast the same for prosecutors within it. The EU is not marked by any national identity as developed over centuries in federations like Germany, nor would prosecutors within it serve a purpose to which all states over which they have jurisdiction have 'signed up' as those of the OTP do. Supra-national prosecutors within the EU would also open a new chapter for such criminal justice agents in multi-level systems.

The status quo, however, as Wade points out should also be unpalatable to all.

"The study ... highlights deficits: the European perspective is not as discernible as it should be, even to experienced practitioners; cases cannot be tackled as they should be, are inadequately investigated and are frequently subject to incomplete prosecution at a level viewed as unacceptable by a majority of study interviewees. The practitioners interviewed in the course of the study indicate that European cases see practitioners on many levels still facing clear limitations in their ability to tackle these successfully."

Should the idea of a supra-national prosecutor win the day and the European Union become set to embrace a formal multi-level criminal justice system, with fragile support, a further range of problems naturally awaits those tasked with the creation of such an office. Prosecutors in multi-level governance settings, particularly the EU, are thus a topic likely to remain with us.

Prosecutors currently working in supra-national agencies, especially within the EU, are already to be witnessed informally negotiating a supra-national function of sorts. They must straddle their positions as national prosecutor aiding their colleagues and co-operative figure supporting those who sit down their office corridor but stem from different member states. There may be much to critique in this and various other set-ups, however, the particular potential of prosecutors forming links and operating effectively within multi-level governance networks should also be acknowledged. Whilst for example, the UK legal system struggles to ensure the European Arrest Warrant is only enforced proportionally, German and French prosecutors report rejecting disproportionate warrants as an expression of their constitutional duties towards their country's citizens or due to their understanding of their office respectively. Prosecutorial discretion can, of course, also be used to secure freedom. When Fair Trials International sought to prevent the deportation of Edmund Arapi (http:// www.fairtrials.net/cases/article/edmond_arapi), clearly caught in a Kafkaesque web of mistaken identity made potent by the efficiency of European criminal justice mechanisms, it was a national prosecutor, exercising powers to withdraw a warrant and not the courts, who prevented extradition and thus saw justice done.

The efficacy of the networks operating within multi-level governance structures will also provide for situations in which one is grateful for pragmatic set-ups which can provide quick solutions. As quasi-judicial figures used to exercising discretion 'in the interests of justice' prosecutors today seem well placed to provide such solutions. This is, however, also an example of a prosecutors being called upon to fill gaps left in ill-conceived "systems." Fundamental questions surround such cases, even where they 
end well. Above all: are such decisions behind closed doors desirable? Few could whole-heartedly say yes [8; p. 475] but as the judicial arm of the executive exercises powers within multi-level governance settings, there are possibly instances in which we should be grateful that it is this and not another figure, which exercises them.

The placing of prosecutors in multi-level governance structures appears to leave them as decisive or, where there is a vacuum of executive power, as deciding instances of policy. In other words, placed in structures in which there is no clear executive but in which policy decisions must be made, prosecutors will assume executive duties and forge policies of their own. Even if they produce desirable results, the danger that they may not can only confirm criticism of such structures. Serious questions are raised relating to accountability, policy-setting powers as well as more legal issues such as equality before the law. Even politicians or civil servants; members of governments accustomed to facing issues such as the former, are subject to heavy criticism for failures in multi-level governance contexts. It must be recognised that prosecutors as usually quasi-judicial/executive figures are accustomed as individuals to being guided in their actions and held accountable by institutional hierarchies and to courts. These hierarchies are in turn headed by a specific figure providing political accountability for a prosecution service as a whole as well as policies pursued by it. Where we chose to place prosecutors in other contexts devoid of such structures, it must be recognised that a transplant is being made producing results deemed unacceptable in national settings. If prosecutors in such settings are furthermore required perform tasks way beyond their usual remit, we have no right to be surprised should the result be unhappy.

We then return to concern about the significant problems illustrated by Boyne. In Germany prosecutors are doubtlessly guided by the structures and guidelines laid down by their Länder ministries but how they enforce the federal codes they serve will be determined most clearly by the informal norms of their specific setting. How this is to be formed and regulated in an international setting is a question of enormous dimensions. The OTP of the ICC has set about developing its policy in dialogue with the broader international criminal law community but fundamentally determining its own interpretation of the broad mandate given to it; to be the organ which choses cases to be adjudicated at the highest level of international criminal law. A European public prosecutor looks set to have to determine its own investigative and prosecutorial practices in negotiation with the agencies of the EU and the prosecutors of the member states. No matter what mandate such an office may be given, the details of its everyday work will have to be developed. Whether any example of desirable practice is currently to be found is questionable. It is intended with this special issue to provide a basis for thinking about what this should constitute.

Each of the settings explored in this special issue witness prosecutors working in a policy area which is not clearly guided as a governance-level; not endowed with any specific executive organ (although the Länder governments in Germany are clearly in charge of justice structures they have very limited powers related to the law the prosecutors serve) and it demonstrates them filling or in various stages of striving to fill the vacuum left. Prosecutors in multi-level governance systems make executive decisions. Guided perhaps by an understanding of norms and of their purpose which resembles the judicial, their work at a more abstract, meta-level, is policy-making in nature. Prosecutors look set to become the thinking, quiet figure of criminal justice in multi-level governance settings. Their work deserves and requires our attention. 
Open Access This article is distributed under the terms of the Creative Commons Attribution License which permits any use, distribution, and reproduction in any medium, provided the original author(s) and the source are credited.

\section{References}

1. Amoury-Combs, N. (2007). Guilty pleas in international criminal law - constructing a restitutive justice approach. Stanford University Press.

2. Aubusson de Cavarley, B., Blom, M., Bulenda, T., Elsner, B., Grusczynska, B., Jehle, J.-M., Kremplewski, A., Lewis, C., Peters, J., Smit, P., Sobota, P., Wade, M.L., Zila, J. (2006) Dealing with various offence types in different criminal justice systems - case examples. In J.-M. Jehle and M.L. Wade (Eds.), Coping with overloaded criminal justice systems - the rise of prosecutorial power. Springer.

3. Costa, J. (2004). Eurojust vis-à-vis the european public prosecutor. In J. Apap (Ed.), Justice and home affairs in the EU. Edward Elgar Press.

4. Renaud Dehousse, (2002). MISFITS: EU LAW AND THE TRANSFORMATION OF EUROPEAN GOVERNANCE Jean Monnet Working Paper 2/02 available at: Available at: http://centers.law. nyu.edu/jeanmonnet/archive/papers/02/020201.rtf. ( $3^{\text {rd }}$ September 2012).

5. Finjaut, C., et al. (2000). Introduction in Volume 8/3 of the European Journal of Crime, Criminal Law and Criminal Justice.

6. Jehle, J.-M., and Wade, M.L. (Eds.) (2006). Coping with overloaded criminal justice systems - the rise of prosecutorial power. Springer.

7. Luna, E. and Wade, M.L. (Eds.) (2012). Prosecutors in transnational perspective. Oxford University Press.

8. Papadopoulos, Y. (2007). Problems of democratic accountability in network and multilevel governance. European Law Journal, 13(4), 469-486.

9. Tak, P. (Ed.). (2004). Tasks and powers of the prosecution services in the EU member states. Nijmegen: Wolf.

10. Tak, P. (Ed.). (2005). Tasks and powers of the prosecution services in the EU member states volume II. Nijmegen: Wolf.

11. Vervaele, J. A.E. (2008). The Shaping and reshaping of Eurojust and OLAF in eucrim 3-4/2008. 